\title{
The New African Conservation Convention
}

\author{
By Kai Curry-Lindahl
}

The new African conservation convention, drawn up by IUCN and signed by the African heads of state in September 1968, is now in force. Kai Curry-Lindahl, who has been involved in its rather chequered history, tells here the story of how two conventions, differing in scope, came to be drawn up and how the matter has been resolved.

N SEPTEMBER 1968 the new African Convention for Conservation of Nature and Natural Resources was signed in Algiers by 38 Heads of States or their representatives at the regular summit meeting of the Organisation of African Unity.

This new convention, which supersedes the London Convention of 1933, was drawn up by IUCN, in collaboration with the African governments and with Unesco and FAO, following a request by the OAU in 1965 . The London Convention was a valuable document for its time; it led to the protection of threatened and rare mammals, the enforcement of game legislation, regulation of the trophy trade, the establishment of national parks and game reserves, and so on. But the political reconstruction of Africa after World War II and the continent's conservation needs made its modernisation very desirable. How the new convention came into being is a rather complex story, and it may be worth while to describe the various stages and how the several international organisations concerned became involved.

In 1953 several changes and amendments to the London Convention were suggested at an international conference in Bukavu, convened by the Commission for Technical Co-operation in Africa South of the Sahara (CCTA) and the government of the Belgian Congo, with the participation of Unesco, IUCN, ICBP and the Scientific Council of Africa (CSA). These additions were never incorporated in the Convention, although several countries acted on them in their national legislation. But in the 1960s the desirability of co-ordinating the conservation and management

Abbreviations used in this article (those starred are translated from French):

CCTA* Commission for Technical Co-operation in Africa South of the Sahara

CSA* Scientific Council of Africa

ECA Economic Commission for Africa (United Nations)

FAO Food and Agriculture Organisation (United Nations)

ICBP International Council for Bird Preservation .

IUCN International Union for Conservation of Nature and Natural Resources

OAU Organisation of African Unity

UNDP United Nations Development Programme

Unesco United Nations Education, Scientific and Cultural Organisation

UNSF United Nations Special Fund 
of natural resources in the African states was urged by several international organisations and conferences, and in 1960 the African Forestry Commission of FAO created an ad hoc Working Party on Wildlife Management, charged with drafting an African Convention for the conservation and controlled exploitation of the wild fauna. (Four years later, however, this working party had still not been convened.) The turning point came in 1961 with the Arusha conference on Conservation of Nature and Natural Resources in Modern African States. Organised by IUCN and CCTA with the participation of Unesco and FAO, this was part of IUCN's African Special Project, of which several stages were financed by the United Nations Special Fund through FAO. The Arusha deliberations made clear the need for a modern conservation convention in Africa, not only as a basis for national legislation but also to provide guidelines for conservation policy and action.

\section{African Charter}

The following year the CSA, meeting at Muguga in Kenya, proposed that a draft of a revised London Convention be prepared as a working paper for consideration by governments, and in 1963 the CCTA/CSA, at their session in Dar-es-Salaam, adopted the African Charter for Protection and Conservation of Nature, an excellent document which could serve as a model for other continents or - why not? - for a World Charter. Its eight paragraphs clearly reflect a modern conservation approach based on ecological principles, and provide a firm basis on which to build a detailed convention. In September, the IUCN General Assembly, meeting in Nairobi, fully endorsed the African Charter but also stressed the importance of co-ordinating all conservation laws.

Finally, in 1964, at Lagos, an International Conference on the Organisation of Research and Training in Africa in Relation to the Study, Conservation and Utilisation of Natural Resources, organised by Unesco and the United Nations Economic Commission for Africa and attended by 28 African countries as well as by FAO, recommended that 'the 1933 conventions on the flora and fauna of Africa be revised in order to bring it up to date and to extend the scope of its application', and also that the OAU be invited to entrust the preparation of a preliminary draft to IUCN, assisted by Unesco and FAO. This was done in a letter from OAU of June 8th 1956, (copied to FAO and ECA), asking the Director General of Unesco to invite IUCN, on their behalf, to undertake the preparation of a convention covering the whole field of natural resources. IUCN immediately set up a working group of the Commission on Legislation, and in September 1965 an IUCN delegation went to Addis Ababa for discussions with the OAU.

The same month, September 1965, in Kampala, the FAO ad hoc Working Party (created in 1960) met for the first time, and decided to let the FAO secretariat prepare a draft convention on the conservation and management of wildlife and its habitats to be circulated for comments among African member countries and international organisations.

In December IUCN convened in Morges, Switzerland, a meeting of African experts including representatives of FAO, Unesco, OAU and 
ECA, to examine the first draft of the African Convention for Conservation of Nature and Natural Resources. Based on deliberations and suggestions produced by this meeting, IUCN prepared a second preliminary draft and submitted it a year later (December, 1966) to OAU, which distributed copies to its member states and convened a meeting to discuss it in Addis Ababa, on May 6th 1967, to which IUCN was invited.

Meantime, in February 1966, FAO had distributed the draft of an African Convention for Conservation and Management of Wildlife and its Habitats to member governments and organisations. By December comments had been received from most of them, and in February 1967 the FAO working party held its second session in Fort Lamy, in Chad, to finalise its draft Convention. Twenty African countries and representatives from the United Nations, Unesco and IUCN were present, and a special committee, composed of delegates from ten countries and the IUCN observer, was appointed to consider the draft. At its first meeting the committee discussed the relationship between the proposed FAO convention on Conservation and Management of Wildlife and its Habitats and the wider convention being prepared by OAU and IUCN, and questioned whether it was realistic to proceed with the FAO convention if the OAU-IUCN were working on another. As IUCN observer, I explained the position of IUCN in relation to the two conventions, stressing that the FAO Working Party had formally a mandate to fulfil, that the draft was well prepared and in an advanced stage, that a detailed document for the conservation of wildlife and its habitats was most desirable and urgent, that IUCN in principle supported the FAO document and had already contributed to the draft, and that my instructions were to assist and help the African governments as much as possible. I recommended that the special committee should go ahead with its work, and this was unanimously agreed (Curry-Lindahl 1967). At the final plenary session of the Fort Lamy conference, the amended draft convention was submitted by the Special Committee, and, with minor alterations, unanimously approved. However, the working party requested FAO to prepare the lists of protected species to be annexed to the Convention in collaboration with IUCN's Survival Service Commission. In July FAO requested IUCN's help and the lists were submitted by IUCN in November.

The OAU meeting scheduled to meet in Addis Ababa in May 1967 was cancelled, but the CSA, meeting there in April, recommended the acceptance of the draft of the IUCN convention after amendments from member states had been taken into consideration. The same month FAO informed IUCN that it planned a 'diplomatic conference to be held early in 1968 for the final adoption of the wildlife convention', with which IUCN was invited to be associated. In September, at the OAU summit meeting (Council of Ministers) of the African Heads of State and Government in Kinshasa, a unanimous resolution reaffirmed that only one conservation convention was required, and appointed a committee, consisting of Ethiopia, Chad, Liberia, Uganda and Tanzania, to amend the draft. (For the full text of this resolution see page 126.) In reply, IUCN, in a statement by the President read at the 14th Session of the FAO Conference 
in Rome in November 1967, declared its readiness to 'endeavour to meet the desire of the Ministers of the OAU for a single Convention, in cooperation with Unesco and FAO, and expresses the hope that whatever is formulated at a later date to cover natural resources other than African wildlife can be added as chapters, sections or appendices to the single instrument convention requested by OAU at Kinshasa'.

\section{Last Chance}

Thus at the end of 1967 it was clear that there was a last opportunity for FAO and IUCN to prepare a combined African Convention, and that action must be taken immediately to produce a revised draft in accordance with the wishes expressed by the African States themselves. In January 1968 a joint committee of representatives of FAO, Unesco and IUCN met in Rome and revised the IUCN convention. However, FAO refused to accept either the incorporation of the articles of the FAO convention in the corresponding articles of the wider convention, or their inclusion as an appendix. The only change to which FAO agreed was the substitution of 'Contracting States' for 'Contracting Governments', in conformity with the IUCN convention. The Committee made the only possible compromise. The two conventions became one convention consisting of two parts: the first on conservation of nature and natural resources, the second on conservation and management of wildlife and its habitats. In this form it was submitted to OAU.

In February the Council of Ministers of the OAU met in Addis Ababa to consider the IUCN Convention draft and the report of the committee appointed the previous September. IUCN was invited to these meetings as adviser. The African Governments made it clear that neither the 'Rome compromise' of January 1968 nor the FAO Convention (Fort Lamy 1967) could be considered or discussed, because they were contradictory to the terms of reference of the Kinshasa resolution of September 1967, stating that only one convention was required and that this convention should be the one prepared by IUCN. They considered the 'Rome compromise' as consisting of two different conventions. Being only an adviser, IUCN could not object to the decision of the meeting; the only course left was to help the African Governments, as constructively as possible, to finalise the articles of the convention in relation to the needs of conservation, management and utilisation of natural resources as well as to the points put forward by FAO and Unesco. The final draft was approved in principle and sent to member states, who were asked to submit comments before June 30th 1968. In September this was approved and signed by the African Governments at the meeting of the Heads of State in Algiers.

In January 1969 the Working Party on Wildlife Management of the FAO African Forestry Commission, meeting in Lomé, Togo, with the participation of UNDP, Unesco, IUCN, OAU and other international organisations, and the representatives of 22 African countries, considered with satisfaction the African Convention on Nature and Natural Resources signed by the Heads of States. They also recommended to the African Forestry Commission that the FAO document on the conservation and 
management of wildlife and its habitats, adopted at Fort Lamy in 1967, be given the widest possible circulation among member nations in order that governments might use it as a technical document in the eventual revision of their national legislation on national parks and wildlife management. A week later the African Forestry Commission adopted this recommendation. By that time several governments had ratified the African Convention on Conservation of Nature and Natural Resources, which means that it is now in force.

\section{Contents of the new Convention}

The articles of the Convention are characterised by a positive attitude to conservation based on broad ecological principles covering not only the preservation, management and utilisation of natural resources-soil, water, vegetation and fauna - but also aspects of research, education, legislation and administration.

The preamble declares that the independent African States are fully conscious of the ever-growing importance of natural resources from economic, cultural and aesthetic points of view as well as of the fact that the utilisation of these natural resources must be regulated by the carrying capacity of the environment. The wild animals are considered as an economically important natural resource compatible with and complementary to other land uses. The contracting states are to ensure conservation and wise use of faunal resources and their environment within the framework of land-use planning. They are also to adopt scientifically-based conservation, management and utilisation plans for forest and rangeland, taking into account the importance of the vegetation cover for the maintenance of the water balance of an area, the productivity of soils and the habitat requirements of the fauna. They are to pay particular attention to the control of bush fires, forest exploitation, clearing for cultivation, overgrazing by domestic animals and the limitation of forest grazing to seasons and intensities that will not prevent forest regeneration.

They recognise that it is important and urgent to accord a special protection to those animal and plant species that are threatened with extinction or which may become so, and to the habitat necessary for their survival, and that where such a species is represented only in the territory of one contracting state, that state has a particular responsibility for its protection. These species are or may be listed, according to the degree of protection that shall be given to them, in class A or B of the Annexe to the Convention, and shall be protected by Contracting States as follows:

(i) Class A species shall be totally protected throughout the entire territory of the contracting states, and the hunting, killing, capture or collection of specimens shall be permitted only on the authorisation in each case of the highest competent authority and only if required in the national interest or for scientific purposes; and

(ii) Class B species shall be totally protected, but may be hunted, killed, captured or collected under special authorisation granted by the competent authority. 
The competent authority of each contracting state shall examine the necessity of applying the provisions of this article to species not listed in the annexe, in order to conserve the indigenous flora and fauna of their respective countries. Such additional species shall be placed in class $\mathbf{A}$ or $B$ by the state concerned, according to its specific requirements. The species in classes A and B are listed on pages 123-125.

As regards national parks, nature reserves and other conservation areas, the contracting states shall maintain and extend, where appropriate, within their territory and, where applicable, in their territorial waters, the conservation areas existing at the time of the entry into force of the present convention, and, preferably within the framework of land-use planning programmes, shall assess the necessity of establishing additional conservation areas in order to:

1 protect those ecosystems which are most representative of and particularly those which are in any respect peculiar to their territories;

2 ensure conservation of all species and more particularly of those listed or to be listed in the Annexe to this Convention.

The contracting states shall establish, where necessary, around the borders of conservation areas, zones within which the competent authorities shall control activities detrimental to the protected natural resources.

The Convention obliges the contracting states to encourage and promote research in conservation, management and utilisation of natural resources, paying particular attention to ecological and sociological factors. In the field of education the contracting states must ensure that their peoples appreciate their close dependence on natural resources and that they understand the need, and rules for, the rational utilisation of these resources by including conservation in educational programmes at all levels and by information campaigns to acquaint the public with, and win its support for, the idea of conservation.

Development plans are often antagonistic to conservation needs. The Convention stipulates that contracting states shall ensure that conservation and management of natural resources are treated as an integral part of national and/or regional development plans. Moreover, in the formulation of all development plans, full consideration should be given to ecological, as well as to economic and social factors. One very important article obliges each contracting state, if it has not already done so, to establish a single agency empowered to deal with all matters covered by the Convention; where this is not possible a co-ordinating machinery must be established for this purpose.

The new African Convention represents a very important step forward in the field of nature conservation in Africa; but it is certainly not the final step. The articles of the Convention must be implemented, centrally as well as provincially, and this cannot be done without an administrative reorganisation with emphasis on conservation. Several governments have already initiated this process. With this new African Convention, independent African states have recognised the fundamental significance for a country's economy and future of the conservation of nature and natural resources. It is an example for other parts of the world to follow. 


\section{LIST OF PROTECTED SPECIES}

\section{CLASS A}

\author{
MAMMALIA \\ Primates \\ Lemuroidea \\ Macaca sylvana \\ Theropithecus gelada \\ Cercocebus galeritus galeritus \\ Cercopithecus diana \\ Colobus badius kirkii \\ Colobus badius rufomitratus \\ Colobus badius gordonorum \\ Colobus verus \\ Pan troglodytes \\ Pan paniscus \\ Gorilla gorilla
}

\section{Rodentia}

Epixerus spp.

\section{Carnivora}

Canis simensis

Osbornictis piscivora

Fossa fossa

Eupleres spp.

Felis nigripes

Felis aurata

Acinonyx jubatus

\section{Pinnipedia}

Monachus monachus

\section{Sirenia}

Dugong dugon

Trichechus senegalensis

\section{Perissodactyla}

Equus asinus

Equus zebra zebra

Ceratotherium simum

\section{Artiodactyla}

Choeropsis liberiensis

Cervus elaphus barbarus

Okapia johnstoni

Taurotragus derbianus derbianus

Cephalophus jentinki

Hippotragus niger variani

Alcelaphus buselaphus tora

Alcelaphus buselaphus swaynei

Nesotragus moschatus moschatus

Dorcatragus megalotis
MAMMALS

All Malagasy lemuroids

Barbary ape

Gelada baboon

Tana River mangabey

Diana monkey

Zanzibar red colobus

Tana River red colobus

Uhehe red colobus

Green colobus

Chimpanzee

Pygmy chimpanzee

Gorilla

\section{Rodentia}

African palm squirrels

\section{Carnivora}

Simenian jackal

Water civet

Malagasy civet

Falanouc

Black-footed cat

African golden cat

Cheetah

\section{Pinnipedia}

Mediterranean monk seal

\section{Sirenia}

Dugong

West African manatee

\section{Perissodactyla}

Wild ass

Cape mountain zebra

Square-lipped rhinoceros
Artiodactyla
Pygmy hippopotamus
Barbary stag
Okapi
Western giant eland
Jentink's duiker
Giant sable antelope
Tora hartebeest
Swayne's hartebeest
Zanzibar suni
Beira antelope 
Gazella dorcas neglecta

Gazella dorcas massaesyla

Gazella gazella cuvieri

Gazella leptocerus leptocerus

Gazella pelzelni

Gazella spekei

Gazella dama mhorr

Gazella dama lozanoi

Capra walie

\section{AVES}

Pelecanidae

Ciconiidae, Scopidae,

Threskiornithidae, Ardeidae and

Plataleidae

Phoenicopteridae

Sagittarius serpentarius

Aegypius, Gyps, Pseudogyps, Torgos,

Trigonoceps, Neophron and Necrosyrtes

Gypaëtus barbatus

Stephanoaëtus coronatus

Falco fasciinucha

Agelastes meleagrides

Afropavo congensis

Gruidae

Bucorvus spp.

Picathartes oreas

Picathartes gymnocephalus

Warsanglia johannis

REPTILIA

Cheloniidae, Dermochelidae

Testudo gigantea

Testudo yniphora

Testudo radiata

Macroscincus coctei

Gecko uroplates

Casarea dussumieri

Bolieria multicarinata

Acrantophis madagascariensis

Acrantophis dumerili

AMPHIBIA

Bufo superciliaris

Nectophrynoides occidentalis

PISCES

Caecobarbus, Caecomastacembelus

Eilichthys, Typhleotris

Phreatichthys, Uegitglanis

\section{PLANTAE}

Welwitschia bainesii

Encephalartos laurentanus

Encephalartos septentrionalis
Algerian dorcas gazelle

Moroccan dorcas gazelle

Cuvier's gazelle

Slender-horned gazelle

Pelzeln's gazelle

Speke's gazelle

Mhorr gazelle

Rio de Oro dama gazelle

Walia ibex

\section{BIRDS}

All pelicans

All storks, hammerkops, ibises, spoon-

bills, herons, egrets and bitterns

\section{All flamingoes \\ Secretary bird}

All vultures

Lammergeyer

Crowned hawk-eagle

Teita falcon

White-headed guineafowl

Congo peacock

All cranes

All ground hornbills

White-necked rockfowl

Grey-necked rockfowl

Warsangli linnet

REPTILES

All marine turtles

Giant tortoise

Angulated tortoise

Radiated tortoise

Cape Verde skink

Leaf-tailed gecko

Plate Island boa

Ronde Island boa

Malagasy boas

\section{AMPHIBIANS \\ Cameroon toad \\ Viviparous toad}

FISHES

Blind fishes

Blind fishes

Blind fishes

\section{PLANTS}

Welwitschia

Encephalartos

Encephalartos 


\section{CLASS B}

\section{MAMMALIA \\ Insectivora}

Potamogalidae

\section{Primates}

Lorisidae

Colobidae and Cercopithecidae

except species of the genus Papio

\section{Pholidota}

Manis gigantea

Manis temmincki

Manis tricuspis

Manis longicaudata

\section{Carnivora}

Lutrinae

Proteles cristatus

Hyaena brunnea

Hyaena hyaena barbara

Felis caracal

Felis serval

Panthera leo

Panthera pardus

Tenrecidae

Cryptoprocta ferox

Galidiinae

\section{Tubulidentata \\ Orycteropus afer}

Proboscidea

Loxodonta africana

Perissodactyla

Equus zebra hartmannae

Equus burchelli

Equus grevyi

Diceros bicornis

\section{Artiodactyla}

Hylochoerus meinertzhageni

Hippopotamus amphibius

Hyemoschus aquaticus

Giraffa camelopardalis

Tragelaphus angasi

Tragelaphus buxtoni

Tragelaphus spekei

Tragelaphus imberbis

Tragelaphus strepsiceros

Taurotragus oryx
MAMMALS

Insectivora

All otter shrews of the family

Potamogalidae

\section{Primates}

All prosimians of the family Lorisidae All monkeys except common baboons

\author{
Pholidota \\ Giant pangolin \\ Cape pangolin \\ Tree pangolin \\ Long-tailed tree pangolin
}

\section{Carnivora}

All otters of the subfamily Lutrinae

Aardwolf

Brown hyaena

Barbary hyaena

Caracal lynx

Serval

Lion

Leopard

Madagascar Tenrecs (all species)

Fossa

All Malagasy mongooses of the subfamily Galidiinae

\section{Tubulidentata \\ Aardvark}

\section{Proboscidea}

Elephant

Perissodactyla

Hartmann's mountain zebra

Burchell's zebra

Grévy's zebra

Black rhinoceros

\section{Artiodactyla}

Giant forest hog

Hippopotamus

Water chevrotain

Giraffe

Nyala

Mountain nyala

Situtunga

Lesser kudu

Greater kudu

Eland 
Taurotragus derbianus

Boocercus eurycerus

Syncerus caffer

Cephalophus adersi

Cephalophus ogilbyi

Cephalophus silvicultor

Cephalophus spadix

Cephalophus zebra

Kobus ellipsiprymnus

Kobus defassa

Kobus leche

Kobus megaceros

Adenota kob

Redunca arundinum

Redunca fulvorufula

Redunca redunca

Hippotragus equinus

Hippotragus niger

Oryx gazella

Oryx tao

Addax nasomaculatus

Damaliscus lunatus

Damaliscus korrigum

Damaliscus dorcas dorcas

Damaliscus dorcas phillipsi

Damaliscus hunteri

Alcelaphus buselaphus

Alcelaphus lichtensteini

Connochaetes gnou

Connochaetes taurinus

Oreotragus oreotragus

Ourebia spp.

Neotragus pygmaeus

Neotragus batesi

Madoqua kirki

Aepyceros melampus

Ammodorcas clarkei

Litocranius walleri

Gazella dorcas

Gazella rufifrons

Gazella tilonura

Gazella dama

Gazella soemmerringi

Capra ibex nubiana

Ammotragus lervia

AVES

Struthio camelus

Falconiformes and Strigiformes

Otididae

REPTILIA

Crocodylia
Giant eland

Bongo

Buffalo

Zanzibar duiker

Ogilby's duiker

Yellow-backed duiker

Abbott's duiker

Banded duiker

Waterbuck

Defassa waterbuck

Lechwe

Nile lechwe

Kob

Reedbuck

Mountain reedbuck

Bohor reedbuck

Roan antelope

Sable antelope

Oryx

Scimitar-horned oryx

Addax

Tsessebe (Sassaby)

Topi

Bontebok

Blesbok

Hunter's hartebeest

Hartebeest

Lichtenstein's hartebeest

Black wildebeest

Wildebeest

Klipspringer

Oribis (all species)

Royal antelope

Dwarf antelope

Damara dikdik

Impala

Dibatag

Gerenuk

Dorcas gazelle

Korin gazelle

Heuglin's gazelle

Dama gazelle

Soemmering's gazelle

Nubian ibex

Barbary sheep (Aoudad)

BIRDS

Ostrich

All birds of prey and all owls not in

Class A

All bustards

REPTILES

All crocodiles 


\section{REFERENCES}

CURRY-LINDAHL, K., 1967 Report on the Second Session of the ad hoc Working Party on Wildlife Management of the African Forestry Commission of FAO, held at Fort Lamy, February 6-11th 1967, on the invitation of the Government of Chad and followed by a study tour to the Zakouma National Park, February 12-13th 1967. Mimeographed IUCN Report, pp 1-8.

\section{OAU Summit Meeting Resolution, September 1967}

Noting that the OAU Charter has requested for co-ordination, harmonisation and intensification of activities in this field; convinced that there is an urgent need to ensure that Member States are guided by common provisions in one convention in the scientific conservation, preservation and exploitation of all of their natural resources for the benefit of man;

1 Thanks the IUCN, Unesco, FAO and all of those who have helped in the drawing up of the preliminary draft African Convention on the Conservation of Nature and Natural Resources;

2 Requests those Member States who have not done so to communicate their views on that draft to the General Secretariat as soon as possible;

3 Accepts that the draft should be amended where necessary, processed and applied to enable Member States to gain the experience that would guide them in their future common action in these matters;

4 Appoints a Committee consisting of Ethiopia, Chad, Libya, Uganda and Tanzania which should meet immediately before the next session of the Council of Ministers, to amend that draft after considering proposals from Member States, and report to the Council of Ministers;

5 Reaffirms that only one general Convention on the Conservation, Preservation and Exploitation of Nature and all Natural Resources is required at present in Africa.

ORYX by AIRMAIL

Overseas members who would like their copies of ORYX sent by second-class airmail are asked to add the appropriate amount to their next annual subscription, using the following table:

Europe, USSR

Ethiopia, Sudan, Middle East

Africa (other than Ethiopia and

Sudan), Asia, Antarctica, Canada, USA, South America, West Indies

Australasia, Japan, Pacific 3s 3d

$14 \mathrm{~s} 0 \mathrm{~d}$

$16 s 8 d(\$ 2.00)$

$19 \mathrm{~s} 4 \mathrm{~d}(\$ 2.50)$

Please note that the minimum annual subscription will be £3 0s Od (\$7.75) from January 1 st 1970 - see page 86. 